神経線維腫 2 型症例の聴覚回復について

蝸牛インプラントと脳幹インプラント

\author{
森田 明夫
}

日本医科大学医学研究科脳神経外科学

\title{
Recovery of hearing function in cases with NF2
}

\section{Cochlear implant and Brainstem implant}

Akio Morita

Department of Neurological Surgery, Graduate School of Medicine, Nippon Medical School


図 1

神経線維腫症 2 型は両側聴神経腫瘍を主兆候とし，最終 的には聴覚を失ってしまうことが多い常染色体優性遺伝疾 患である. 本症例の患者さん（少なくとも私の元に訪れる 患者）は，非常に真面目で，どのような障害を背負っても 労働なり, 何かの役に立とうと思っている人が多い. その ような患者さんに聴覚を回復させてあげる技術をもつこと は医療者としては至上の喜びである，現在そのような目的
で行われているのが蝸牛インプラント及び脳幹インプラン 卜（医療機器としては未承認のため自費診療）である。螖 牛インプラントを埋め込む症例は蝸牛神経を解剖学的（生 理的）に温存できた症例であり, 比較的小さな症例が対象 となる. 図 1, 2 に 20 代の聴覚をほぼ失った男性の例を示 す。聴覚のよかった右の腫瘍が急激に拡大し聴覚を失っ た. 螖牛神経を温存するように腫瘍を皮膜を残して摘出し

Correspondence to Akio Morita, MD, PhD, Department of Neurological Surgery Graduate School of Medicine, Nippon Medical School 1-1-5 Sendagi, Bunkyo-ku, Tokyo 113-8602, Japan E-mail: amor-tky@nms.ac.jp Journal Website (http://www2.nms.ac.jp/jmanms/) 

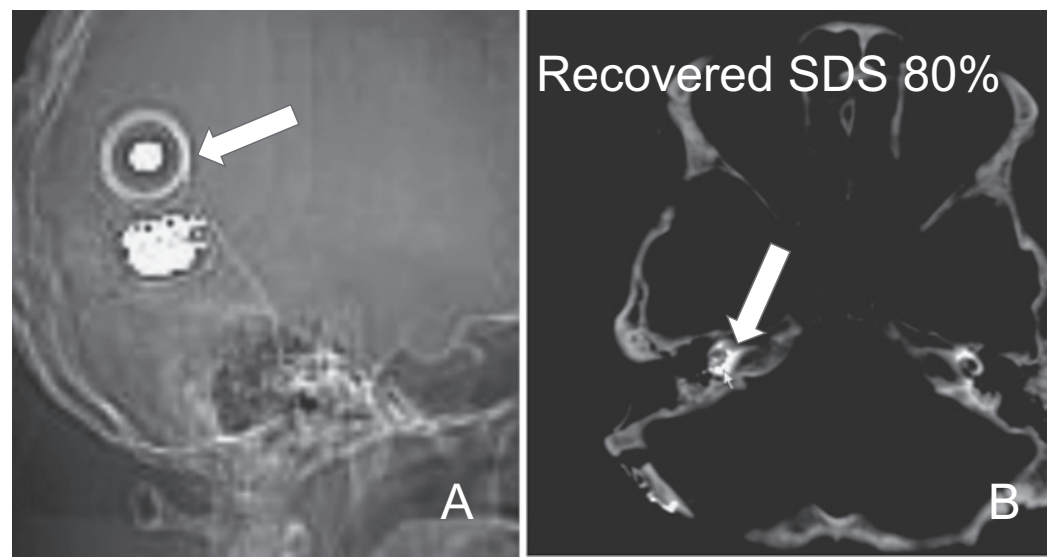

図 2
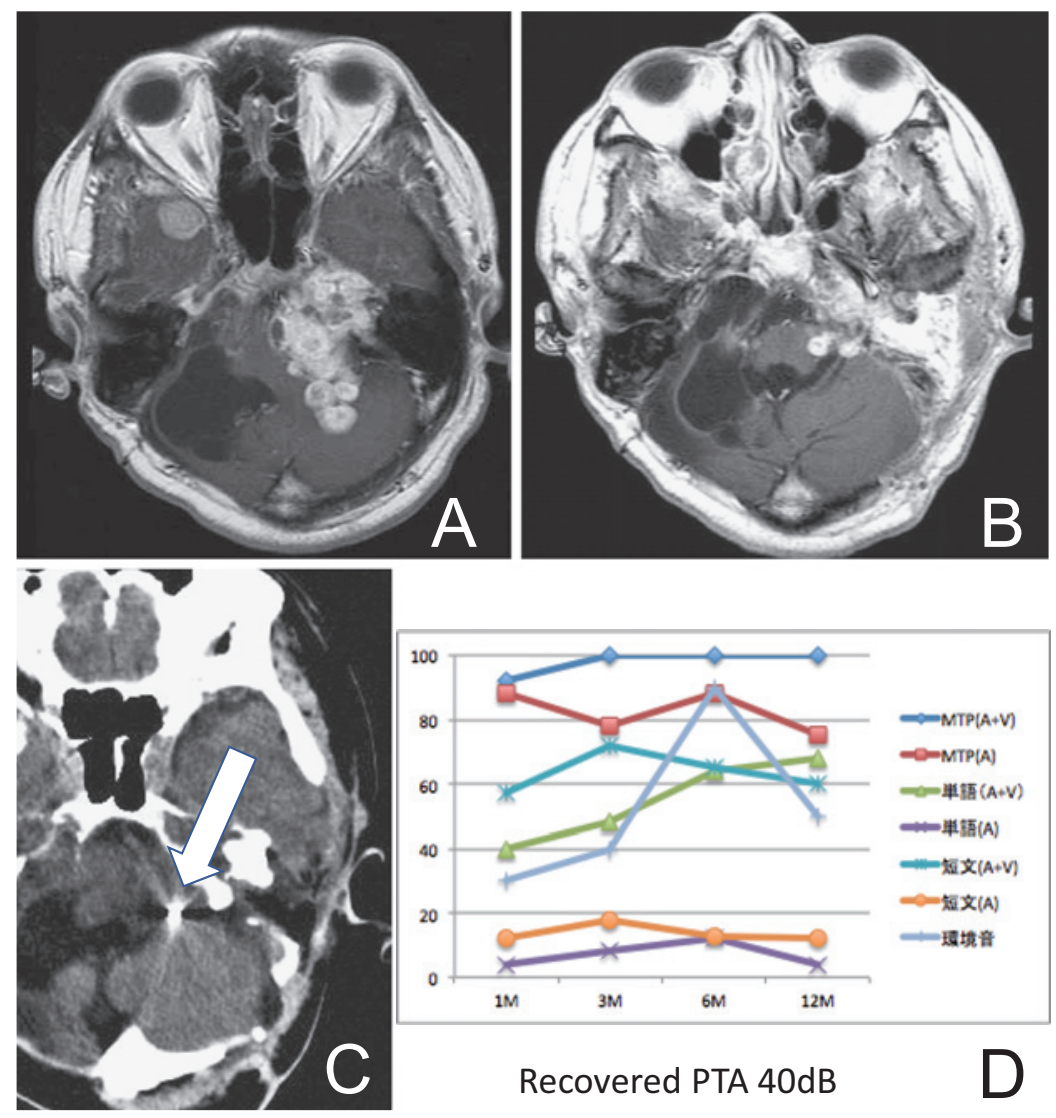

Recovered PTA 40dB

D

図 3

（図 1)，後日螖牛インプラント（図 2）を埋め込んだ。直 後よりきわめて有効な聴覚を回復し, 現在語音明瞭度は 80\%である. 制約や問題なく就労している. 腫瘍が大き く神経を残すことが不可能である例や長期に蝸牛神経機能 が障害されている患者では脳幹インプラントの適応とな る。脳幹に直接電極を留置して電気信号として音情報を脳 幹一聴覚路に伝達する. 図 3 はそのような治療を行った 30

図120 代男性 A：腫瘍の急激な拡大で右聴覚を消失し 聴覚が低下 $\mathrm{B}, \mathrm{C}$ : 蝸牛神経を残すように腫瘍を摘出 $\mathrm{D}$ : 皮膜と少し腫瘍を残して摘出

図2 蝸牛インプラントを留置 A : 白矢印 頭蓋レシー バー B：白矢印 右蝸牛内電極
代の症例である。大型の腫瘍を摘出し, 脳幹インプラント を留置した. 13 年間聾の状態であったが, 聴覚を回復し, 現 在顔を見て話せば（少し唇読が加われば） $70 \%$ 程度の理 解を得られ筆談を必要としない。奥様の声を初めて聞いた と喜ばれている。このような感覚情報を外部から神経系に 機器を用いて伝達する方法は確立されつつある．将来的に は視覚の情報を伝達できる技術を開発したいと思っている.

図3 30 代男性 13 年来の䆍 $\mathrm{A}, \mathrm{B}$ ：大型の腫瘍を摘出 $\mathrm{C}$ : 白矢印脳幹蝸牛神経核上に留置した電極 D : A 聴覚と $\mathrm{V}$ 視覚を用いて言語理解が向上している。単語は $70 \%$ ，短文は $60 \%$ を理解できるようになっている. 